\title{
ANALISA PENYUSUTAN PRODUK PLASTIK PADA PROSES INJECTION MOLDING MENGGUNAKAN MEDIA PENDINGIN COOLING TOWER DAN UDARA DENGAN MATERIAL POLYPROPYLENE
}

\section{ANALYSIS OF PLASTIC DEPRECIATION ON INJECTION MOLDING PROCESS USING COOLANT MEDIA OF COOLING TOWER AND AIR WITH POLYPROPYLENE MATERIAL}

\author{
Anwar Ilmar Ramadhan ${ }^{1 *}$, Ery Diniardi ${ }^{1}$, Muhamad Daroji ${ }^{1}$ \\ ${ }^{1}$ Jurusan Teknik Mesin, Fakultas Teknik, Univeristas Muhammadiyah Jakarta \\ Jl. Cempaka Putih Tengah 27 Jakarta Pusat 10510 Indonesia \\ *E-mail : anwar.ilmar@ftumj.ac.id
}

Histori Artikel:

Submitted:

$19 / 06 / 2017$

Revised:

$12 / 07 / 2017$

Accepted:

$24 / 07 / 2017$

\section{Abstrak}

Shrinkage merupakan suatu cacat berupa perubahan dimensi produk hasil proses injection molding. Pendinginan mold merupakan salah satu faktor yang mempengaruhi cacat produk shrinkage. Pendinginan pada mold dapat dilakukan dengan media pendinginan udara ( air cooling) atau fluida (water cooling). Pemanfaatannya tergantung dari efektivitas pendinginan yang perlu dicapai sehingga produk cepat berada pada batas temperatur sentak yang diijinkan sesuai material plastik, fasilitas yang tersedia dan konstruksi pendinginan yang mendukung. Pengujian dilakukan menggunakan material polypropylene dengan parameter yang konstan seperti waktu injeksi 1 detik, tekanan injeksi 650 bar, kecepatan injeksi $25 \mathrm{~mm} / \mathrm{s}$ dan temperatur leleh $230^{\circ} \mathrm{C}-240^{\circ} \mathrm{C}$, serta variabel backpressure yang digunakan pada masing - masing zat pendinginan yaitu $15 \mathrm{kgf} / \mathrm{cm}^{2}, 25 \mathrm{kgf} / \mathrm{cm}^{2}$, dan $35 \mathrm{kgf} / \mathrm{cm}^{2}$. Pada pengujian pendinginan cooling tower dengan menggunakan settingan temperatur leleh $230^{\circ} \mathrm{C}$ $240^{\circ} \mathrm{C}$ dengan waktu injeksi 1 detik dan backpressure $15 \mathrm{kgf} / \mathrm{cm}^{2}$ nilai shrinkage-nya adalah 1,65\%, dan backpressure $25 \mathrm{kgf} / \mathrm{cm}^{2}$ nilai shrinkagenya $1,57 \%$ serta pada backpressure $35 \mathrm{kgf} / \mathrm{cm}^{2}$ nilai shrinkage-nya adalah 1,49 \%. Pada pengujian menggunakan pendinginan udara dengan menggunakan settingan yang sama seperti pada pendinginan cooling tower didapat nilai shrinkage pada backpressure $15 \mathrm{kgf} / \mathrm{cm}^{2}$ adalah 1,78 \%, dan backpressure $25 \mathrm{kgf} / \mathrm{cm}^{2}$ nilai shrinkage sebesar 1,7\%, serta pada backpressure $35 \mathrm{kgf} / \mathrm{cm}^{2}$ nilai shrinkage-nya adalah 1,61\%. Berdasarkan hasil pengujian, shrinkage pada pengujian injection molding dengan pendinginan cooling tower lebih kecil dibandingkan pada pengujian injection molding dengan pendinginan udara. Hal ini disebabkan karena laju perpindahan panas konveksi maupun konduksi yang terjadi pada pendinginan cooling tower lebih baik dibandingkan dengan menggunakan pendinginan udara, sehingga pemerataan panas pada mold akan lebih merata dan akan memiliki temperatur yang konstan.

Kata kunci: Shrinkage, Material plastik, Pendingianan Mold, Perpindahan Panas 


\begin{abstract}
Shrinkage is a defect which makes the product dimensions of injection molding process change. Mold cooling is one of the factors that shrinkage defect. Cooling mold can be done by air cooling or water cooling. The function depends on the effectiveness of cooling which needs to be achieved in order to make the product reaches on the hitch temperature limit as the plastic material used, the available facilities and the supported cooling constructed. The test was conducted using a polypropylene material with constant parameters such as 1 second injection time, 650 bar of injection pressure, $25 \mathrm{~mm} / \mathrm{s}$ of injection speed and $230^{\circ} \mathrm{C}-240^{\circ} \mathrm{C}$ of melting temperature, as well as backpressure variable used in each cooling agents are 15 $\mathrm{kgf} / \mathrm{cm}^{2}, 25 \mathrm{kgf} / \mathrm{cm}^{2}$, and $35 \mathrm{kgf} / \mathrm{cm}^{2}$. On the testing of cooling tower and use setting the melting temperature of $230^{\circ} \mathrm{C}-240^{\circ} \mathrm{C}$ with 1 second injection time and backpressure $15 \mathrm{kgf} / \mathrm{cm}^{2}$ shrinkage of its value is $1,65 \%$, and the backpressure $25 \mathrm{kgf} / \mathrm{cm}^{2}$ shrinkage of its value is $1,57 \%$ as well as the backpressure $35 \mathrm{kgf} / \mathrm{cm}^{2}$ shrinkage of its value is 1,49\%. On testing using air cooling and using the same setting as in the cooling tower, shrinkage values obtained in backpressure $15 \mathrm{kgf} / \mathrm{cm}^{2}$ is $1,78 \%$, and backpressure $25 \mathrm{kgf} / \mathrm{cm}^{2}$ shrinkage of its value is $1,7 \%$, as well as the backpressure $35 \mathrm{kgf} / \mathrm{cm}^{2}$ shrinkage of its value is $1,61 \%$. Based on the result of testing, test of shrinkage in injection molding with cooling tower is smaller than the test injection molding with air cooling. This is because the rate of convection and conduction heat transfer that occurs in cooling tower is better than using air cooling in the mold, so that heat distribution will be uneven and will have a constant temperature.
\end{abstract}

Keywords : Shrinkage, plastic materials, mold cooling, heat transfer

\section{PENDAHULUAN}

Plastik merupakan suatu polimer yang memiliki sifat - sifat yang luar biasa. Plastik yang digunakan untuk kemasan memiliki berbagai kelebihan, diantaranya yaitu fleksibel, bentuk laminasi (aneka warna, tidak mudah rusak, dan harga yang relatif murah) dan transparan (Akbarzadeh, et al, 2011). Material plastik yang digunakan dalam pembuatan produk plastik diantaranya yaitu polypropylene, polyetilene, polystyrene, dan lain - lain (Amri, 2009, Anggono, 2005, Awaluddin, 2012). Polypropylene digunakan dalam berbagai aplikasi, seperti komponen otomotif, perlengkapan laboratorium, tempat makanan ataupun minuman. Polyetilene biasa digunakan untuk kemasan botol susu, botol detergen maupun pipa air (Budiarto, 2011). Polystyrene digunakan untuk pembuatan cashing TV, lensa yang terbuat dari plastik dan masih banyak lainnya (Febriantoko, 2008).

Proses injection molding merupakan proses yang kompleks karena melibatkan beberapa langkah - langkah proses yang diawali dengan langkah pengisian material yaitu material plastik yang leleh akan mengalir dari unit injeksi melalui sprue, runner, gate dan masuk ke dalam cavity. Material plastik yang terdapat di dalam cavity kemudian ditahan di dalam mold dibawah tekanan tertentu untuk menjaga adanya shrinkage selama produk mengalami pendinginan (Firdaus, 2002, Kamaruddin, 2010).

Permasalahan umum yang sering terjadi pada industri injeksi plastik adalah adanya penyusutan pada produk hasil proses injeksi. Dalam proses injection molding terdapat banyak parameter yang dapat mempengaruhi hasil injeksi (Gede, 2004, Deden, 2005). Adapun parameter - parameter tersebut adalah holding time, inject time, cooling time, mold temperature dan lain - lain. Jika salah satu parameter proses injeksi tersebut diabaikan, maka hasil benda cetakan tersebut kurang baik antara lain akan timbul cacat shrinkage pada benda hasil cetakan (Santoso, 2014). Shrinkage merupakan suatu cacat berupa perubahan dimensi produk hasil proses injection molding.

Pendinginan mold merupakan salah satu faktor yang mempengaruhi cacat produk shrinkage. Penggunaan media untuk pendinginan mold di PT XYZ yaitu dengan menggunakan cooling tower dan water chiller. Namun, jika terdapat kondisi mold yang kurang baik seperti mold bocor atau terdapat retak pada daerah insert cavity atau insert core serta output untuk pengiriman bersifat urgent, maka pendinginan harus menggunakan udara untuk sementara waktu hingga mold dijadwalkan untuk diperbaiki setelah selesai produksi.

Melihat kejadian seperti ini, mencoba untuk menganalisa penyusutan produk plastik yang terjadi antara pendinginan menggunakan udara dan cooling tower dengan material 
polypropylene. Penelitian tentang analisa penyusutan produk plastik pada proses injection molding menggunakan media pendinginan cooling tower dan udara untuk mengetahui gambaran mengenai besaran nilai penyusutan antara cooling tower dan udara.

Tujuan penelitian adalah untuk mengetahui besarnya nilai shrinkage atau penyusutan antara media pendingin cooling tower dan udara pada proses injection molding.

\section{METODE PENELITIAN}

Penelitian ini dilakukan untuk menganalisa penyusutan produk plastik pada proses injection molding menggunakan media pendingin cooling tower dan udara yang dimaksudkan untuk mengetahui pengaruh pendinginan pada mold terhadap seberapa besar nilai cacat penyusutan dimensi produk plastik antara media pendinginan cooling tower dan udara serta untuk mengetahui pengaruh terhadap efektifitas yang terjadi dalam proses injection molding. Berikut ini tahapan yang akan dilakukan untuk menyelesaikan analisa yaitu sebagai berikut :

1. Tahap persiapan

Untuk mengetahui faktor - faktor penyebab terjadinya shrinkage perlu dilakukan tahapan persiapan baik itu dengan studi pustaka serta survey di lapangan. Studi pustaka dapat dilakukan dengan menggunakan beberapa literatur dari buku dan jurnal, sedangkan survey lapangan dengan melakukan eksperimen langsung di area produksi injection molding.

\section{Persiapan mold}

Sebelum melakukan eksperimen di area produksi injection molding perlu dilakukan persiapan mold yang akan dilakukan eksperimen. Mold atau cetakan yang dipilih untuk eksperimen terbuat dari material STAVAX.

\section{Eksperimen proses injeksi}

Tahapan ini dilakukan untuk memperoleh data - data penyusutan dimensi atau ukuran produk plastik yang menggunakan media pendinginan cooling tower dan udara. a) Proses injection molding pendinginan cooling tower

Proses ini dilakukan dengan cara melakukan pendinginan dengan air yang disalurkan ke dalam saluran pendingin mold atau cetakan selama siklus proses berlangsung hingga menghasilkan produk plastik.

b) Proses injection molding pendinginan udara Proses ini dilakukan tidak menggunakan air dalam pendinginannya, melainkan menggunakan udara yang dihasilkan dari kompresor yang sudah dialiri ke saluran pipa udara dan udara tersebut dialirkan melalui saluran pendingin yang terdapat di dalam mold atau cetakan.

4. Analisa penyusutan ukuran produk

Pada tahap ini hasil penelitian dilakukan analisa terhadap data yang telah didapat. Tahapan analisa ini dilakukan dengan mengukur dimensi produk plastik, melakukan perhitungan shrinkage dan disajikan dalam bentuk grafik untuk mengetahui nilai penyusutan antara pendinginan cooling tower dan udara.

\section{HASIL DAN PEMBAHASAN}

\section{A. Perpindahan Panas Konduksi}

Perhitungan perpindahan panas konduksi dilakukan pada bagian fix cavity plate. Berikut ini adalah fenomena perpindahan panas konduksi, seperti pada Gambar 1.

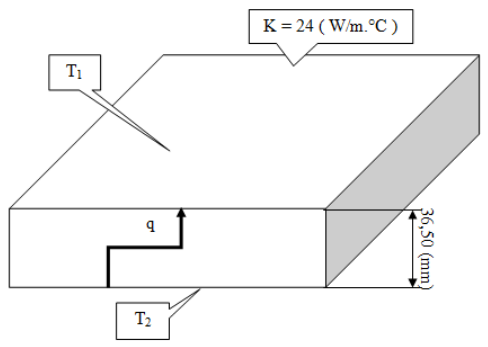

Gambar 1. Fenomena konduksi

a. Konduksi pada Cooling Tower

$$
\mathrm{q}=\frac{\mathrm{kA}\left(\mathrm{T}_{2}-\mathrm{T}_{1}\right)}{\mathrm{L}}
$$


Dimana :

- nilai konduktivitas panas material stavax ( $\mathrm{k}$ ) yaitu $24\left(\mathrm{~W} / \mathrm{m} .{ }^{\circ} \mathrm{C}\right)$

- $\mathrm{T}_{1}=$ temperatur rata-rata permukaan pelat atas $=37\left({ }^{\circ} \mathrm{C}\right)$

- $\mathrm{T}_{2}=$ temperatur rata-rata permukaan pelat bawah $=50\left({ }^{\circ} \mathrm{C}\right)$

- $\mathrm{L}=$ tebal pelat $=0,0365(\mathrm{~m})$

- $\mathrm{A}=$ luas penampang aliran panas $=\mathrm{p} \times \mathrm{l}=0,3$ (m) $\times 0,25(\mathrm{~m})=0,075\left(\mathrm{~m}^{2}\right)$

Maka,

$$
\begin{aligned}
& \mathrm{q}=\frac{24\left(\mathrm{~W} / \mathrm{m} \cdot{ }^{\circ} \mathrm{C}\right) \cdot 0,075\left(\mathrm{~m}^{2}\right)\left[50\left({ }^{\circ} \mathrm{C}\right)-37\left({ }^{\circ} \mathrm{C}\right)\right]}{0,0365 \mathrm{~m}} \\
& \mathrm{q}=\frac{24\left(\mathrm{~W} / \mathrm{m} \cdot{ }^{\circ} \mathrm{C}\right) \cdot 0,075\left(\mathrm{~m}^{2}\right) \cdot 13\left({ }^{\circ} \mathrm{C}\right)}{0,0365(\mathrm{~m})} \\
& \mathrm{q}=641,096(\mathrm{~W})
\end{aligned}
$$

Jadi, laju perpindahan panas konduksi yang terjadi pada saat menggunakan pendinginan cooling tower adalah sebesar 41,096 (W).

b. Konduksi pada udara

Diketahui nilai temperatur pada pengukuran sebagai berikut :

$\mathrm{T}_{1}=43\left({ }^{\circ} \mathrm{C}\right) \& \mathrm{~T}_{2}=61\left({ }^{\circ} \mathrm{C}\right)$

Maka,

$$
\begin{aligned}
& \mathrm{q}=\frac{24\left(\mathrm{~W} / \mathrm{m} \cdot{ }^{\circ} \mathrm{C}\right) \cdot 0,075\left(\mathrm{~m}^{2}\right)\left[61\left({ }^{\circ} \mathrm{C}\right)-43\left({ }^{\circ} \mathrm{C}\right)\right]}{0,0365(\mathrm{~m})} \\
& \mathrm{q}=\frac{24\left(\mathrm{~W} / \mathrm{m} \cdot{ }^{\circ} \mathrm{C}\right) \cdot 0,075\left(\mathrm{~m}^{2}\right) \cdot 18\left({ }^{\circ} \mathrm{C}\right)}{0,0365(\mathrm{~m})} \\
& \mathrm{q}=887,671(\mathrm{~W})
\end{aligned}
$$

Jadi, laju perpindahan panas konduksi (q) yang terjadi pada saat menggunakan pendinginan udara adalah sekitar 887,671 (W)

\section{B. Perpindahan Panas Konveksi}

Perhitungan perpindahan panas konveksi dilakukan pada bagian fix cavity plate. Berikut ini adalah fenomena perpindahan panas konveksi.

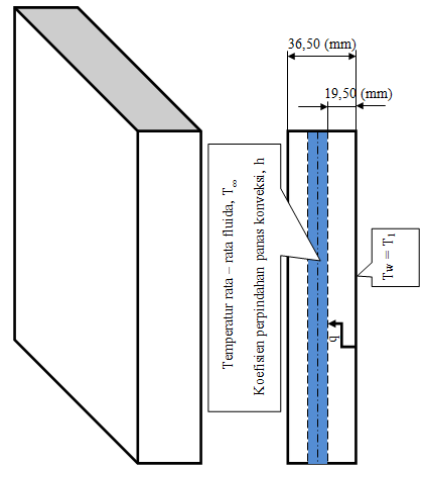

Gambar 2. Fenomena konveksi

a. Konveksi pada cooling tower $\mathrm{q}=\mathrm{hA}\left(\mathrm{T}_{\mathrm{w}}-\mathrm{T}_{\infty}\right)$

Dimana :

- $\mathrm{A}=$ luas penampang aliran panas

$$
=\mathrm{p} \times \mathrm{l}=0,3(\mathrm{~m}) \times 0,25(\mathrm{~m})
$$

$$
=0,075\left(\mathrm{~m}^{2}\right)
$$

- $\mathrm{T}_{\mathrm{w}}=$ temperatur rata-rata permukaan pelat atas $=\mathrm{T}_{1}=37\left({ }^{\circ} \mathrm{C}\right)$

- $\mathrm{T}_{\infty}=$ temperatur fluida $=33,2\left({ }^{\circ} \mathrm{C}\right)$

- $\mathrm{k}=$ konduktivitas termal air

$$
=0,556\left(\mathrm{~W} / \mathrm{m} .{ }^{\circ} \mathrm{C}\right)
$$

Menentukan kecepatan rata-rata fluida :

$\mathrm{V}=\mathrm{Q} / \mathrm{A}$

dimana :

$\mathrm{Q}=$ kapasitas fluida yang melewati fix cavity plate $=8,8404 \times 10^{-9}\left(\mathrm{~m}^{3} / \mathrm{s}\right)$

$\mathrm{A}=$ luasan lubang cooling

$=6,3585 \times 10^{-5}\left(\mathrm{~m}^{2}\right)$

maka,

$\mathrm{V}=\mathrm{Q} / \mathrm{A}$

$$
\begin{aligned}
& =\frac{8,8404 \times 10^{-9}\left(\mathrm{~m}^{3} / \mathrm{s}\right)}{6,3585 \times 10^{-5}\left(\mathrm{~m}^{2}\right)} \\
& =1,39 \times 10^{-4}(\mathrm{~m} / \mathrm{s})
\end{aligned}
$$

Menentukan bilangan Reynold :

$\mathrm{Re}=\mathrm{V} \cdot \mathrm{d} / \mathrm{v}$

dimana :

$\mathrm{V}=$ kecepatan rata-rata fluida

$\mathrm{d}=$ diameter lubang cooling mold

$$
=9(\mathrm{~mm})
$$

$\mathrm{v}=$ viskositas kinematik air pada

temperatur $33,2\left({ }^{\circ} \mathrm{C}\right)$ 


$$
=7,55172 \times 10^{-7}\left(\mathrm{~m}^{2} / \mathrm{s}\right)
$$

maka,

$$
\begin{aligned}
\mathrm{R}_{\mathrm{e}} & =\mathrm{V} \cdot \mathrm{d} / \mathrm{v} \\
& =\frac{1,39 \times 10^{-4}(\mathrm{~m} / \mathrm{s}) \cdot 9 \times 10^{-3}(\mathrm{~m})}{7,55172 \times 10^{-7}\left(\mathrm{~m}^{2} / \mathrm{s}\right)} \\
& =1,66
\end{aligned}
$$

Menentukan bilangan Nusselt:

$\mathrm{Nu}=0,023 \cdot \mathrm{Re}_{\mathrm{e}}^{0,8} \cdot \mathrm{Pr}^{\mathrm{n}}$

$$
\begin{aligned}
& \text { Dimana: } \\
& \mathrm{Nu}=\text { bilangan Nusselt } \\
& \mathrm{Re}_{\mathrm{e}}=\text { bilangan Reynold }=1,66 \\
& \mathrm{Pr}=\text { bilangan Prandtl } \\
& \mathrm{Pr}=5,0812 \text {, pada temperatur } 33,2 \\
& \mathrm{n}=0,4 \text { untuk pemanasan, karena } \mathrm{d} \\
& \quad \text { lebih panas dari fluida yang menga } \\
& \text { maka, nilai bilangan Nusselt }(\mathrm{Nu}): \\
& \mathrm{Nu}=0,023 \cdot \mathrm{Re}^{0,8} \cdot \mathrm{Pr}^{\mathrm{n}} \\
& \mathrm{Nu}=0,023 \cdot 1,66^{0,8} \cdot 5,0812^{0,4} \\
& \quad=0,066
\end{aligned}
$$$$
\operatorname{Pr}=5,0812 \text {, pada temperatur } 33,2\left({ }^{\circ} \mathrm{C}\right)
$$$$
\mathrm{n}=0,4 \text { untuk pemanasan, karena dinding }
$$$$
\text { lebih panas dari fluida yang mengalir }
$$

Menentukan koefisien perpindahan panas konveksi (h) :

$\mathrm{h}=\mathrm{Nu} \cdot \mathrm{k} / \mathrm{d}$

dimana :

$\mathrm{h} \quad=$ koefisien perpindahan panas konveksi $\left(\mathrm{W} / \mathrm{m}^{2} .{ }^{\circ} \mathrm{C}\right)$

$\mathrm{Nu}=$ bilangan Nusselt $=0,066$

$\mathrm{k}=$ koefisien konduktivitas panas air $=0,556\left(\mathrm{~W} / \mathrm{m} .{ }^{\circ} \mathrm{C}\right)$

$\mathrm{d} \quad=$ jarak permukaan fix cavity plate bagian atas ke air $=19,50(\mathrm{~mm})$

maka, koefisien perpindahan panas konveksi ( $\mathrm{h}$ ):

$\mathrm{h} \quad=\mathrm{Nu} \cdot \mathrm{k} / \mathrm{d}$

$=\frac{0,066 \cdot 0,556\left(\mathrm{~W} / \mathrm{m} \cdot{ }^{\circ} \mathrm{C}\right)}{0,0195 \mathrm{~m}}$

$=1,88\left(\mathrm{~W} / \mathrm{m}^{2} .{ }^{\circ} \mathrm{C}\right)$

Laju perpindahan panas konveksi (q):

$\mathrm{q}=\mathrm{hA}\left(\mathrm{T}_{\mathrm{w}}-\mathrm{T}_{\infty}\right)$

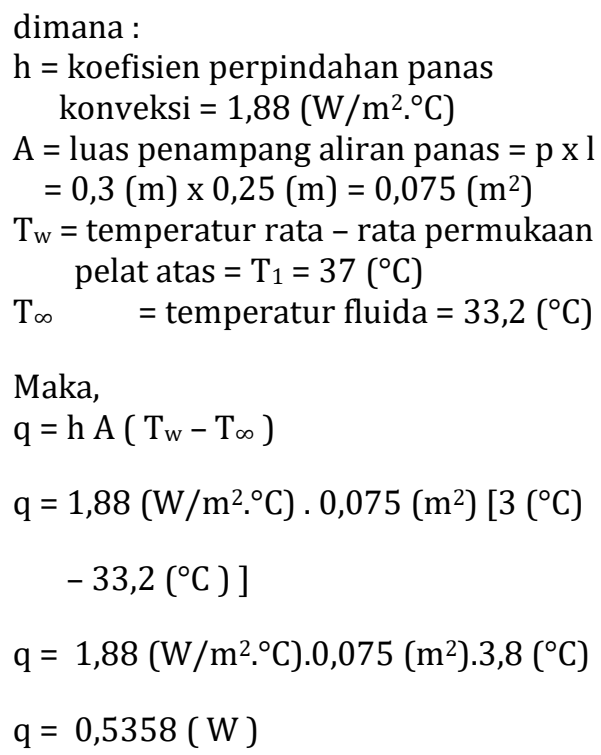

dimana :

$\mathrm{h}=$ koefisien perpindahan panas konveksi $=1,88\left(\mathrm{~W} / \mathrm{m}^{2} .{ }^{\circ} \mathrm{C}\right)$

$\mathrm{A}=$ luas penampang aliran panas $=\mathrm{p} \times \mathrm{l}$

$=0,3(\mathrm{~m}) \times 0,25(\mathrm{~m})=0,075\left(\mathrm{~m}^{2}\right)$

$\mathrm{T}_{\mathrm{w}}=$ temperatur rata - rata permukaan pelat atas $=\mathrm{T}_{1}=37\left({ }^{\circ} \mathrm{C}\right)$

$\mathrm{T}_{\infty} \quad=$ temperatur fluida $=33,2\left({ }^{\circ} \mathrm{C}\right)$

Maka,

$\mathrm{q}=\mathrm{hA}\left(\mathrm{T}_{\mathrm{w}}-\mathrm{T}_{\infty}\right)$

$\mathrm{q}=1,88\left(\mathrm{~W} / \mathrm{m}^{2} \cdot{ }^{\circ} \mathrm{C}\right) \cdot 0,075\left(\mathrm{~m}^{2}\right)\left[3\left({ }^{\circ} \mathrm{C}\right)\right.$

$\left.-33,2\left({ }^{\circ} \mathrm{C}\right)\right]$

$\mathrm{q}=1,88\left(\mathrm{~W} / \mathrm{m}^{2} \cdot{ }^{\circ} \mathrm{C}\right) \cdot 0,075\left(\mathrm{~m}^{2}\right) \cdot 3,8\left({ }^{\circ} \mathrm{C}\right)$

$q=0,5358(W)$

Jadi, panas yang dipindahkan pada jarak permukaan fix cavity plate bagian atas ke air (q) adalah 0,5358 (W).

b. Konveksi pada udara

$$
\mathrm{q}=\mathrm{h} A\left(\mathrm{~T}_{\mathrm{w}}-\mathrm{T}_{\infty}\right)
$$

Dimana :

- $\mathrm{A}=$ luas penampang aliran panas

$$
=\mathrm{p} \times \mathrm{l}=0,3(\mathrm{~m}) \times 0,25(\mathrm{~m})
$$$$
=0,075\left(\mathrm{~m}^{2}\right)
$$

- $\mathrm{T}_{\mathrm{w}}=$ temperatur rata-rata permukaan pelat atas $=\mathrm{T}_{1}=43\left({ }^{\circ} \mathrm{C}\right)$

- $\mathrm{T}_{\infty}=$ temperatur udara $=31,3\left({ }^{\circ} \mathrm{C}\right)$

- $\mathrm{k}=$ konduktivitas termal udara

$$
=0,024\left(\mathrm{~W} / \mathrm{m} .{ }^{\circ} \mathrm{C}\right)
$$

Menentukan kecepatan rata-rata fluida :

$\mathrm{V}=\mathrm{Q} / \mathrm{A}$

dimana :

$\mathrm{Q}=$ kapasitas udara yang melewati fix cavity plate $=8,8404 \times 10^{-9}\left(\mathrm{~m}^{3} / \mathrm{s}\right)$

$\mathrm{A}=$ luasan lubang cooling

$=6,3585 \times 10^{-5}\left(\mathrm{~m}^{2}\right)$

maka,

$$
\begin{aligned}
V & =Q / A \\
& =\frac{8,8404 \times 10^{-9}\left(\mathrm{~m}^{3} / \mathrm{s}\right)}{6,3585 \times 10^{-5}\left(\mathrm{~m}^{2}\right)} \\
& =1,39 \times 10^{-4}(\mathrm{~m} / \mathrm{s})
\end{aligned}
$$

Menentukan bilangan Reynold : 
$\mathrm{Re}=\mathrm{V} \cdot \mathrm{d} / \mathrm{v}$

dimana :

$\mathrm{V}=$ kecepatan rata-rata fluida

$\mathrm{d}=$ diameter lubang cooling mold

$=9(\mathrm{~mm})$

$\mathrm{v}=$ viskositas kinematik udara pada

temperatur $31,3\left({ }^{\circ} \mathrm{C}\right)$

$=1,6078 \times 10^{-5}\left(\mathrm{~m}^{2} / \mathrm{s}\right)$

maka, bilangan Reynold $\left(\mathrm{R}_{\mathrm{e}}\right)$ :

$\mathrm{R}_{\mathrm{e}}=\mathrm{V} \cdot \mathrm{d} / \mathrm{v}$

$$
\begin{aligned}
& =\frac{1,39 \times 10^{-4}(\mathrm{~m} / \mathrm{s}) \cdot 9 \times 10^{-3}(\mathrm{~m})}{1,6078 \times 10^{-5}\left(\mathrm{~m}^{2} / \mathrm{s}\right)} \\
& =0,078
\end{aligned}
$$

Menentukan bilangan Nusselt:

$\mathrm{Nu}=0,023 \cdot \mathrm{Re}_{\mathrm{e}}{ }^{0,8} \cdot \operatorname{Pr}^{\mathrm{n}}$

Dimana:

$\mathrm{Nu}=$ bilangan Nusselt

$\mathrm{R}_{\mathrm{e}}=$ bilangan Reynold $=0,078$

$\mathrm{Pr}=$ bilangan Prandtl

$\operatorname{Pr}=0,71187$, pada temperatur $31,3\left({ }^{\circ} \mathrm{C}\right)$

$\mathrm{n}=0,4$ untuk pemanasan, karena dinding

lebih panas dari fluida yang mengalir

maka, nilai bilangan Nusselt $(\mathrm{Nu})$ :

$\mathrm{Nu}=0,023 \cdot \mathrm{Re}^{0,8} \cdot \operatorname{Pr}^{\mathrm{n}}$

$$
\begin{aligned}
\mathrm{Nu} & =0,023 \cdot 0,078^{0,8} \cdot 0,71187^{0,4} \\
& =0,002608
\end{aligned}
$$

Menentukan koefisien perpindahan panas konveksi (h) :

$\mathrm{h}=\mathrm{Nu} \cdot \mathrm{k} / \mathrm{d}$

dimana :

$\mathrm{h} \quad=$ koefisien perpindahan panas konveksi $\left(\mathrm{W} / \mathrm{m}^{2} .{ }^{\circ} \mathrm{C}\right)$

$\mathrm{Nu}=$ bilangan Nusselt $=0,002608$

$\mathrm{k}=$ koefisien konduktivitas panas udara $=0,024\left(\mathrm{~W} / \mathrm{m} .{ }^{\circ} \mathrm{C}\right)$

$\mathrm{d} \quad=$ jarak permukaan fix cavity plate bagian atas ke air $=19,50(\mathrm{~mm})$

maka, koefisien perpindahan panas konveksi ( $\mathrm{h}$ ) :

$\mathrm{h}=\mathrm{Nu} \cdot \mathrm{k} / \mathrm{d}$

$=\underline{0,002608 \cdot 0,024\left(\mathrm{~W} / \mathrm{m} \cdot{ }^{\circ} \mathrm{C}\right)}$

$$
\begin{gathered}
0,0195 \mathrm{~m} \\
=0,00321\left(\mathrm{~W} / \mathrm{m}^{2} .^{\circ} \mathrm{C}\right)
\end{gathered}
$$

Laju perpindahan panas konveksi (q):

$$
\begin{aligned}
& \mathrm{q}=\mathrm{h} A\left(\mathrm{~T}_{\mathrm{w}}-\mathrm{T}_{\infty}\right) \\
& \text { dimana : } \\
& \mathrm{h}=\text { koefisien perpindahan panas } \\
& \text { konveksi }=0,00321\left(\mathrm{~W} / \mathrm{m}^{2}{ }^{\circ} \mathrm{C}\right) \\
& \mathrm{A}=\text { luas penampang aliran panas }=\mathrm{p} \times \mathrm{l} \\
& =0,3(\mathrm{~m}) \times 0,25(\mathrm{~m})=0,075\left(\mathrm{~m}^{2}\right) \\
& \mathrm{T}_{\mathrm{w}}=\text { temperatur rata }- \text { rata permukaan } \\
& \text { pelat atas }=\mathrm{T}_{1}=43\left({ }^{\circ} \mathrm{C}\right) \\
& \mathrm{T}_{\infty} \quad=\text { temperatur udara }=31,3\left({ }^{\circ} \mathrm{C}\right) \\
& \text { Maka, } \\
& \mathrm{q}=\mathrm{hA}\left(\mathrm{T}_{\mathrm{w}}-\mathrm{T}_{\infty}\right) \\
& \mathrm{q}=0,00321\left(\mathrm{~W} / \mathrm{m}^{2} \cdot{ }^{\circ} \mathrm{C}\right) \cdot 0,075\left(\mathrm{~m}^{2}\right) \\
& {\left[43\left({ }^{\circ} \mathrm{C}\right)-31,3\left({ }^{\circ} \mathrm{C}\right)\right]} \\
& \mathrm{q}=0,00321\left(\mathrm{~W} / \mathrm{m}^{2} \cdot{ }^{\circ} \mathrm{C}\right) \cdot 0,075\left(\mathrm{~m}^{2}\right) \text {. } \\
& 11,7\left({ }^{\circ} \mathrm{C}\right) \\
& q=0,00282(W)
\end{aligned}
$$

Jadi, panas yang dipindahkan pada jarak permukaan fix cavity plate bagian atas ke udara (q) adalah 0,00282 (W).

\section{Laju Kalor yang Diserap}

Dengan data yang ada pada spesifikasi cooling tower yang terlampir. Bahwa air yang dialirkan dari cooling tower mempunyai debit 1575 (liter/min). Cooling tower yang digunakan mempunyai bak dengan diameter minimal 3300 (mm) dan tinggi 2485 (mm). Piping connections yang digunakan untuk inlet 125 $(\mathrm{mm})$, outlet $125(\mathrm{~mm})$, over flow $50(\mathrm{~mm})$, dan fan motor yang digunakan 5 (HP).

Dari data heat exchanger didapatkan :

Laju aliran air yang dibutuhkan 1 unit heat exchanger adalah :

$$
\begin{aligned}
\mathrm{Q}_{1} & =1575(\text { liter } / \mathrm{min})=94500(\text { liter } / \mathrm{jam}) \\
& =94,5\left(\mathrm{~m}^{3} / \mathrm{jam}\right)
\end{aligned}
$$

Dengan faktor koreksi $20 \%$ sehingga laju aliran air menjadi :

$\mathrm{Q}_{1}=1,2 \times 94,5\left(\mathrm{~m}^{3} / \mathrm{jam}\right)$ 


$$
\begin{aligned}
& =113,4\left(\mathrm{~m}^{3} / \mathrm{jam}\right) \\
& =0,0315\left(\mathrm{~m}^{3} / \text { detik }\right)
\end{aligned}
$$

Temperatur air masuk heat exchanger sisi shell $=$ $32\left({ }^{\circ} \mathrm{C}\right)$

Temperatur air keluar heat exchanger sisi shell $=$ $37\left({ }^{\circ} \mathrm{C}\right)$

Laju kalor yang diserap air pendingin dihitung dengan persamaan :

$\mathrm{q}=\dot{\mathrm{m}} \times \mathrm{Cp}_{\text {air }} \times \Delta \mathrm{T}$

dimana :

$$
\begin{array}{ll}
\mathrm{q} & =\text { laju kalor yang diserap } \\
\mathrm{m} & =\text { massa }=\mathrm{Q} \times \rho \\
\mathrm{Cp}_{\text {air }} & =4,179\left(\mathrm{~kJ} / \mathrm{kg} .{ }^{\circ} \mathrm{K}\right) \\
\Delta \mathrm{T} & =\text { perubahan temperatur } \\
\rho & =\text { massa jenis } \\
\rho & =995\left(\mathrm{~kg} / \mathrm{m}^{3}\right), \text { pada temperatur } \\
& 32\left({ }^{\circ} \mathrm{C}\right)
\end{array}
$$

maka, nilai $\rho$ (massa jenis) pada temperatur 32 $\left({ }^{\circ} \mathrm{C}\right)$ adalah $995\left(\mathrm{~kg} / \mathrm{m}^{3}\right)$

Jadi, laju kalor yang diserap sebesar :

$$
\begin{aligned}
\mathrm{q}= & \dot{\mathrm{m}} \times \mathrm{Cp}_{\text {air }} \times \Delta \mathrm{T} \\
= & 3,97(\mathrm{~kg} / \text { detik }) \times 4,179\left(\mathrm{~kJ} / \mathrm{kg} \cdot{ }^{\circ} \mathrm{K}\right) \\
& \mathrm{x}\left[310,15\left({ }^{\circ} \mathrm{K}\right)-305,15\left({ }^{\circ} \mathrm{K}\right)\right] \\
= & 82,95315(\mathrm{~kW}) \\
= & 82953,15(\mathrm{~W})
\end{aligned}
$$

Maka, cooling tower mampu menerima dan melepaskan kalor sebesar 82953,15 (W)

\section{Data Pengujian Pendinginan dengan cooling tower}

1) Pengujian $I$

Waktu injeksi 1 detik dengan backpressure 15 $\left(\mathrm{kgf} / \mathrm{cm}^{2}\right)$ dan temperatur leleh $230\left({ }^{\circ} \mathrm{C}\right)-$ $240\left({ }^{\circ} \mathrm{C}\right)$.

$$
\begin{aligned}
& S=\frac{d o-d}{d} \times 100 \% \\
& S=\frac{52,79-51,92}{52,79} \times 100 \%=1,65 \%
\end{aligned}
$$

2) Pengujian II

Waktu injeksi 1 detik dengan backpressure 25 $\left(\mathrm{kgf} / \mathrm{cm}^{2}\right)$ dan temperatur leleh $230\left({ }^{\circ} \mathrm{C}\right)-$ $240\left({ }^{\circ} \mathrm{C}\right)$.

$$
S=\frac{52,79-51,96}{52,79} \times 100 \%=1,57 \%
$$

3) Pengujian III

Waktu injeksi 1 detik dengan backpressure 35 $\left(\mathrm{kgf} / \mathrm{cm}^{2}\right)$ dan temperatur leleh $230\left({ }^{\circ} \mathrm{C}\right)-$ $240\left({ }^{\circ} \mathrm{C}\right)$.

$$
S=\frac{52,79-52,00}{52,79} \times 100 \%=1,49 \%
$$

Hasil dari perhitungan hasil pengujian dapat dilihat pada Tabel 1.

Tabel 1. Hasil Data Pengujian Pendinginan dengan Cooling Tower

\begin{tabular}{|c|c|c|c|c|c|}
\hline No & $\begin{array}{c}\text { Waktu } \\
\text { Injeksi }(\mathrm{sec})\end{array}$ & $\begin{array}{c}\text { Backpressure } \\
\left(\mathrm{kgf} / \mathrm{cm}^{2}\right)\end{array}$ & $\begin{array}{c}\text { Mold Temp. } \\
\left({ }^{\circ} \mathrm{C}\right)\end{array}$ & $\begin{array}{c}\mathrm{d} \\
(\mathrm{mm})\end{array}$ & $\begin{array}{c}\text { Shrinkage } \\
(\%)\end{array}$ \\
\hline 1 & 1 & 15 & 40 & 51.92 & 1.65 \\
\hline 2 & 1 & 15 & 40 & 51.92 & 1.65 \\
\hline 3 & 1 & 15 & 40 & 51.92 & 1.65 \\
\hline 5 & 1 & 25 & 35 & 51.96 & 1.57 \\
\hline 6 & 1 & 25 & 35 & 51.96 & 1.57 \\
\hline 7 & 1 & 25 & 35 & 51.96 & 1.57 \\
\hline 8 & 1 & 35 & 30 & 52.00 & 1.49 \\
\hline 9 & 1 & 35 & 30 & 52.00 & 1.49 \\
\hline
\end{tabular}

Tabel 1 diatas dapat dibuatkan grafik hubungan antara Shrinkage (\%) terhadap Temperatur mold $\left({ }^{\circ} \mathrm{C}\right)$, dapat dilihat pada Gambar 3 .

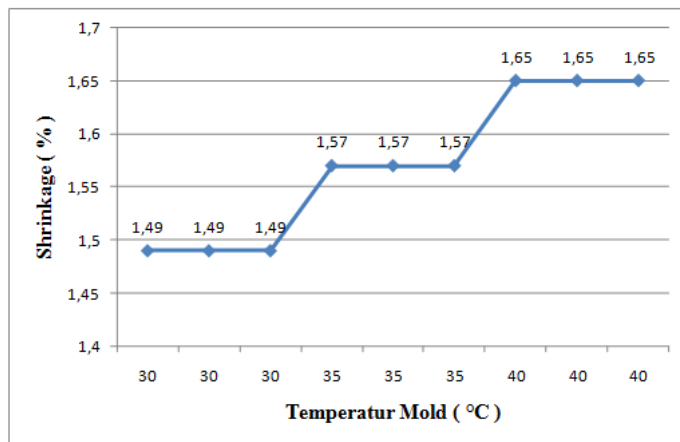

Gambar 3. Grafik Hubungan Antara Temperatur Mold dengan Shrinkage

Pada Tabel 1 diatas dapat dibuatkan juga grafik hubungan antara Shrinkage (\%) terhadap Backpressure $\left(\mathrm{kgf} / \mathrm{cm}^{2}\right)$, dapat dilihat pada Gambar 4. 


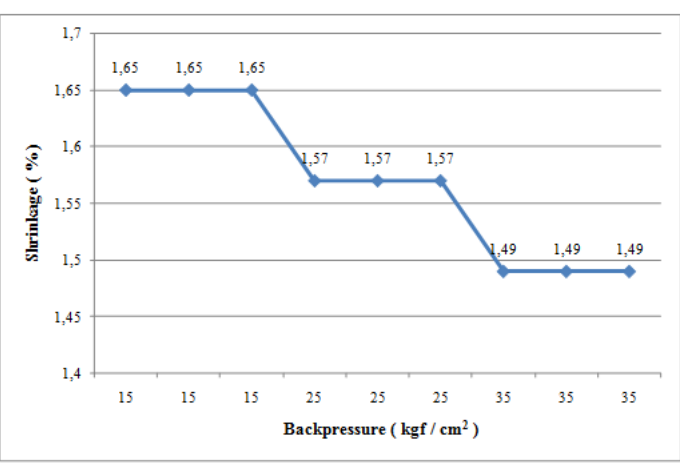

Gambar 4. Grafik Hubungan Antara Backpressure dengan Shrinkage

\section{E. Data Pengujian Pendinginan dengan udara}

1) Pengujian $I$

Waktu injeksi 1 detik dengan backpressure 15 $\left(\mathrm{kgf} / \mathrm{cm}^{2}\right)$ dan temperatur leleh $230\left({ }^{\circ} \mathrm{C}\right)-$ $240\left({ }^{\circ} \mathrm{C}\right)$.

$$
\begin{aligned}
& S=\frac{d_{0}-d}{d} \times 100 \% \\
& S=\frac{52,79-51,85}{52,79} \times 100 \%=1,78 \%
\end{aligned}
$$

2) Pengujian II

Waktu injeksi 1 detik dengan backpressure 25 $\left(\mathrm{kgf} / \mathrm{cm}^{2}\right)$ dan temperatur leleh $230\left({ }^{\circ} \mathrm{C}\right)-$ $240\left({ }^{\circ} \mathrm{C}\right)$.

$$
S=\frac{52,79-51,89}{52,79} \times 100 \%=1,70 \%
$$

3) Pengujian III

Waktu injeksi 1 detik dengan backpressure 35 $\left(\mathrm{kgf} / \mathrm{cm}^{2}\right)$ dan temperatur leleh $230\left({ }^{\circ} \mathrm{C}\right)-$ $240\left({ }^{\circ} \mathrm{C}\right)$.

$$
S=\frac{52,79-51,94}{52,79} \times 100 \%=1,61 \%
$$

Hasil dari perhitungan hasil pengujian dapat dilihat pada Tabel 2 .

Tabel 2. Hasil Data Pengujian Pendinginan dengan Udara

\begin{tabular}{|c|c|c|c|c|c|}
\hline No & $\begin{array}{c}\text { Waktu } \\
\text { Injeksi }(\mathrm{sec})\end{array}$ & $\begin{array}{c}\text { Backpressure } \\
\left(\mathrm{kgf} / \mathrm{cm}^{2}\right)\end{array}$ & $\begin{array}{c}\text { Mold Temp. } \\
\left({ }^{\circ} \mathrm{C}\right)\end{array}$ & $\begin{array}{c}\mathrm{d} \\
(\mathrm{mm})\end{array}$ & $\begin{array}{c}\text { Shrinkage } \\
(\%)\end{array}$ \\
\hline 1 & 1 & 15 & 55 & 51.85 & 1.78 \\
\hline 2 & 1 & 15 & 55 & 51.85 & 1.78 \\
\hline 3 & 1 & 15 & 55 & 51.85 & 1.78 \\
\hline 4 & 1 & 25 & 50 & 51.89 & 1.70 \\
\hline 5 & 1 & 25 & 50 & 51.89 & 1.70 \\
\hline 6 & 1 & 25 & 50 & 51.89 & 1.70 \\
7 & 1 & 35 & 45 & 51.94 & 1.61 \\
\hline 8 & 1 & 35 & 45 & 51.94 & 1.61 \\
9 & 1 & 35 & 45 & 51.94 & 1.61 \\
\hline
\end{tabular}

Tabel 2 diatas dapat dibuatkan grafik hubungan antara Shrinkage (\%) terhadap Temperatur mold $\left({ }^{\circ} \mathrm{C}\right)$, dapat dilihat pada Gambar 5.

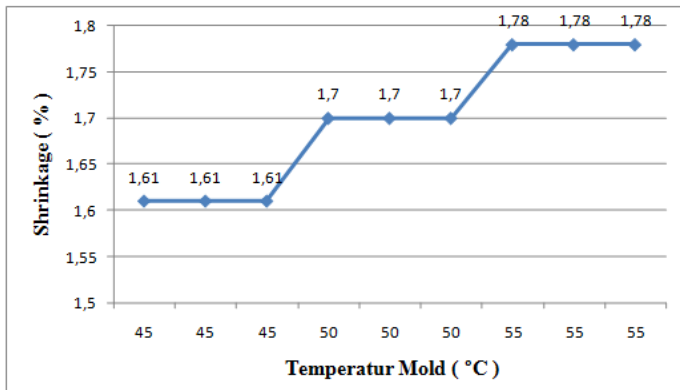

Gambar 5 Grafik Hubungan Antara Temperatur Mold dengan Shrinkage

Pada Tabel 2 diatas dapat dibuatkan juga grafik hubungan antara Shrinkage (\%) terhadap Backpressure (kgf/cm2), dapat dilihat pada Gambar 6.

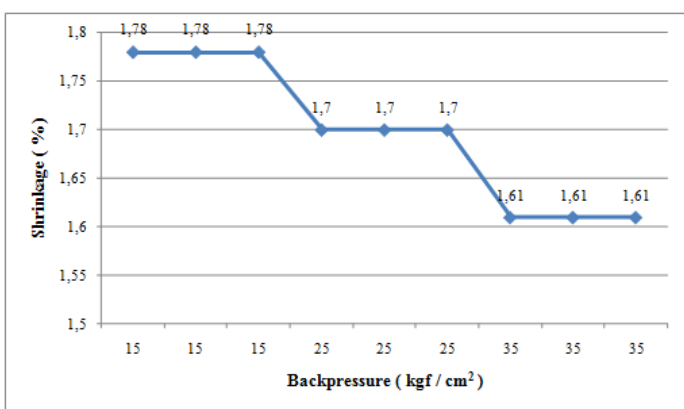

Gambar 6. Grafik Hubungan Antara Backpressure dengan Shrinkage

Pengujian dilakukan pada produk yang memiliki ketebalan 0,8 (mm). Temperatur yang tinggi digunakan untuk mempercepat pengisian material ke dalam rongga mold karena semakin tinggi temperatur maka semakin rendah viskositasnya. Tetapi hal ini berdampak pada penyusutan produk yang semakin besar. 


\begin{tabular}{|c|}
\hline  \\
\hline
\end{tabular}

\section{KESIMPULAN}

Berdasarkan hasil analisa dan pengujian serta pembahasan data yang diperoleh tentang shrinkage atau penyusutan antara pendinginan mold menggunakan pendingin cooling tower dan udara dapat disimpulkan bahwa pendinginan pada proses injection molding sangat berpengaruh terhadap shrinkage produk. Hal ini dapat diketahui pada laju perpindahan panas konveksi yang terjadi antara penggunaan media pendingin cooling tower dan udara. Pada penggunaan pendinginan udara, panas yang dapat dipindahkan nilainya sangat kecil sehingga berdampak pada temperatur mold yang terjadi. Selain pendinginan mold, faktor yang menyebabkan terjadinya shrinkage yaitu parameter proses injection molding dan jenis material plastik yang digunakan.

Pengujian yang dilakukan untuk mendapatkan nilai shrinkage dalam pengujian antara pendinginan cooling tower dan udara dengan material polypropylene yaitu menggunakan parameter proses injection molding yang konstan seperti waktu injeksi 1 detik, tekanan injeksi 650 bar, kecepatan injeksi $25(\mathrm{~mm} / \mathrm{s})$ dan temperatur leleh $230-240\left({ }^{\circ} \mathrm{C}\right)$, serta backpressure yang digunakan pada masing - masing media pendingin yaitu 15, 25, dan 35 ( $\mathrm{kgf} / \mathrm{cm}^{2}$ ). Maka dapat disimpulkan besarnya nilai shrinkage antara media pendingin cooling tower yaitu sebagai berikut:

1. Nilai shrinkage atau penyusutan material polypropylene terbesar terjadi pada pendinginan menggunakan udara dengan backpressure $15\left(\mathrm{~kg} / \mathrm{cm}^{3}\right)$ yaitu sebesar $1,78 \%$.

2. Nilai shrinkage atau penyusutan material polypropylene terkecil terjadi pada pendinginan menggunakan cooling tower dengan backpressure $35\left(\mathrm{~kg} / \mathrm{cm}^{3}\right)$ yaitu sebesar $1,49 \%$.

Penggunaan pendinginan pada mold dengan menggunakan pendingin cooling tower dan udara akan berpengaruh pada temperatur mold yang terjadi. Dalam analisa yang dilakukan, pendinginan yang baik antara media pendingin cooling tower dan udara yaitu dengan menggunakan pendingin air. Penggunaan pendinginan udara mengakibatkan temperatur yang terjadi pada mold akan memiliki temperatur yang tidak konstan sehingga pemerataan panas pada mold akan tidak merata dan akan berdampak pada besarnya shrinkage atau penyusutan. 


\section{DAFTAR PUSTAKA}

Akbarzadeh, A., Sadeghi, M., 2011, Parameter Study in Plastic Injection Molding Process using Statistical Methods and IWO Algoritm, International Journal Modeling And Obtimization, Vol. 1, No. 2, June 2011.

Amri, Alfan., 2009, Pengaruh Pendinginan Dalam Proses Injection Molding Pembuatan Acetabular Cup Pada Sambungan Hip, Surakarta : Universitas Muhammadiyah Surakarta.

Anggono, A. D., 2005, Prediksi Shrinkage Untuk Menghindari Cacat Produk Pada Plastic Injection, Media Mesin, Vol. 6, No. 2, Juli 2005: 70-77.

Awwaluddin, Muhammad., Santosa Puji., Suwardiyono., 2012, Perhitungan Kebutuhan Cooling Tower Pada Rancang Bangun Untai Uji Sistem Kendali Reaktor Riset, BATAN, Vol. 9, No. 1, ISSN: 14110296.

Badri, MG., 2014, Sifat Mekanik Dan Cacat Penyusutan (Shrinkage) Akibat Variasi Komposisi Campuran Daur Ulang Polyethylene Pada Injection Moulding, Jurnal ROTOR, Vol. 7, No. 1, April 2014.

Budiarto., 2002, Perancangan Peralatan Pencetak, Bandung : Politeknik Manufaktur Bandung.

Febriantoko, B. W., Wibowo, A. H., 2008, Studi Peningkatan Siklus Injeksi Dan Pengurangan Prosentase Penyusutan Pada Produk Injeksi Plastik Dengan Mold Tipe Laminated Steel Tooling, Teknik Mesin, ISBN : 978-979-3980-15-7.

Firdaus, et al., 2002, Studi Eksperimental Pengaruh Parameter Proses Pencetakan Bahan Plastik Terhadap Cacat Penyusutan (Shrinkage) Pada Benda Cetak Pneumatics Holder, Teknik Mesin, Vol. 4, No. 2, Oktober 2002: 75-80.

Gutowski., 2002., Injection Molding Machine.

Harinaldi., Budiarso., 2003, Mekanika Fluida, Jakarta : Erlangga.

Holman, J.P., 1997, Heat Transfer, International Edition: The McGraw-Hill.

Kamaruddin, S., Khan, A. Z., dan Foong, S. H., 2010, Application of Taguchi Method in the Optimization of Injection Moulding Parameters for Manufacturing Products from Plastic Blend, IACSIT International Journal of Engineering and Technology, Vol. 2, No. 6, ISSN: 1793-8236.
Kristanto, Yuli., Kusharjanta, Bambang., Ubaidillah., 2013, Pengaruh Suhu Pemanas Terhadap Shrinkage Pada Proses Injeksi Polypropylene, Mekanika, Vol. 12, No.1, September 2013.

Liang Chi Cooling Tower., Counter Flow Induced Draft (Model LBC)

M. Artama, Gede., 2004, Proses Injection Molding Cycle Pada Injection Molding Machine dan Molding Defect, Yogyakarta : Universitas Gadjah Mada.

Mennig, Günter., 1998, Mold Making Handbook, München : Germany.

Moerbani, J., 1999, Plastic Moulding, Jurnal Akademi Teknik Mesin Industri (ATMI ), Surakarta.

Muhammad, Deden., 2005, Analisa Proses Perpindahan Kalor dan Massa Pada Counter-Flow Cooling Tower, Teknik Fisika, Vol. 1, ISSN: 0216-9681, halaman 39- 48.

Santoso, Slamet Teguh., 2014, Proses Produksi dan Perawatan Mesin Injection Molding, Bekasi : Politeknik Gunakarya Indonesia.

Schey, John A., 2009, Proses Manufaktur, Yogyakarta : ANDI.

Sularso., 2008, Pompa dan Kompresor, Bandung : Institut Teknologi Bandung.

Wahyudi, U., 2014, Studi Pengaruh Injection Time Dan Backpressure Terhadap Cacat Penyusutan Pada Produk Kemasan Toples Dengan Proses Injection Molding Menggunakan Material Polistyrene, Jakarta : Universitas Mercubuana.

Wiwoho, B., 1986, Barometer Bisnis Plastik Indonesia, Jakarta: Yayasan Bina Pembangunan. 